\title{
MUSLIM RELIGIOSITY IN A CHALLENGING SECULAR STATE OF SINGAPORE
}

\author{
Helmiati \\ Universitas Islam Negeri (UIN) Sultan Syarif Kasim Riau \\ emikahar@yahoo.com
}

\begin{abstract}
This article aims to examine the religiosity of Muslim minority living in a Singapore secular state. This survey research draws on Stark and Glock's model of multidimensional religiosity while accommodating specific characteristics of Islamic piety in framing the religiosity. From 482 Singaporean Muslims participated in this survey, this study found that the majority of Singaporean Muslims are quite religious. The finding indicates that religion is a core of their identity and a significant component of their life in spite of living in a secular state. This study argues that Muslim's religious commitment can coexist within a secular framework due to Singapore secularism's unique nature. Similarly, it also asserts that Singaporean Muslims negotiate a prudent balance between their civil responsibilities as Singaporeans and their religious obligations as Muslims. This study implies that secularism is multifaceted in relation to different cultural, political milieus, and different religions. Thus, secularism should not always be crudely viewed as categorical resistance against religion.
\end{abstract}

Keywords: Muslim, Religiosity, Islam, Secular, Singapore 


\section{A. Introduction}

Muslims in Singapore constitute a minority group within a self-proclaimed secular, multi-cultural and multireligious state, in which they only make up $14 \%$ of the population (Department of Statistics, 2015) living within the cultural supremacy dominated by Buddhist and Christian Chinese (Nasir, 2010; Tan, 2016). Living in a secular state, Muslims have been facing many challenges and unfavorable state policies regarding practicing acts of religious piety. These limitations include state prohibition of wearing headscarves by female Muslim students at public schools, nurses, front-line immigration and customs officers (Osman, 2018; Tan, 2016), the exclusion of religious knowledge from public schools (Musa, 2017), and restriction of the seats total number at madrasahs (Nasir, 2010). In fact, there are strong demands among Muslims for religious knowledge (Nasir, 2010). The secular state also excludes religion from politics, resulting in the prohibition of religious groups and leaders from participating in politics (Hang, 2008). This exclusion has been regarded as violating an Islamic principle which argues that Islam is a way of life encompassing every aspect of life including politics (Musa, 2019). Many Singaporean Muslims also consider these disparities between Singapore's laws and religious laws as an impediment to being proper Muslims (MUIS Academy, 2011). These social phenomena indicate that state secularism creates specific challenges to Muslim's religiosity in terms of observing their religious obligation and upholding their religious commitment. These challenges lead to some questions, such as: How is Muslim's religiosity experienced or lived in a secular state like Singapore? How is it to be religious in such a secular state? 
Recent studies analyzing Singaporean Muslims and secular Singapore revealed their challenging circumstances as a minority (Mutalib, 2012), as indicated by the state's use of a coercive and authoritarian approach in governing Muslims through co-opting and controlling the influence of the leading Islamic organizations and relying on draconian legislation (Abdullah, 2013; Rahim, 2012). Singapore's secularism has led tensions on several issues between the Muslim minority and the state authority (Osman, 2018), while Singaporean Muslims embrace the state secularism on the basis of pragmatism despite some disagreement with their Islamic beliefs (Musa, 2019). Apparently, Singaporean authority has been utilizing religion, albeit in a very selective and sanitized manner only for forging national identity (Steiner, 2011). Moreover, studies on Muslim religiosity in such a secular state like Singapore have not yet been conducted to date. In order to fill in this gap, this study attempts to examine the religiosity of Muslim minority living in the challenging secular context. The expected finding of this study determines a theoretical assumption of the extent of Muslim religiosity in a secular state, which will contribute to the growing body of literature on this issue.

\section{B. Theoretical Framework}

\section{Islam's Reconciliation with Challenging Secularism}

Secularism is a contentious notion in Islamic political thought, due in part to the ambiguity of the concept itself and in part to historical factors (Lauzière, 2013). As an ambiguous concept, it could refer to atheism, anticlericalism, the separation of religion and state, state neutralitytoward religion, prohibition of religious symbols 
from the public domain (Hashemi, 2009). Historically, the concept has gained negative connotations for many Muslims, as it has been associated with the elimination of Islamic influences from the political and legal sectors during the colonial period. It has also been connected to the efforts of several secular states to minimize the religious expression in public sphere (Esposito, 1998, 2014; Saeed, 2017). Thus, secularism has always been understood as a foreign ideology enforced by colonialists, preserved by post-colonial ruling elites (Hashemi, 2009), and perceived as equivalent to anti-religion or irreligion (Saeed, 2017).

Some Islamic traditionalists like Al-Attas (1993) and Al-Qaradawi (1997) revealed that secularism is incompatible with Islam, as Islam has provided a comprehensive guide as a self-adequate system regulating all aspects of life. On the other hand, several Islamic reformists such as Mohammed Taha, Abdel Raziq, Abdolkarim Soroush and An-Na'im have supported the notion of a secular state that approves religion as a critical part of everyday lives, as long as it is not utilized as the reference of the state policies (An-Na'im, 2008). Another view comes from Hassan $(1999,2002)$, he argues that it might be prudent to maintain separation of Islam from the state to play an effective role in solving societal problems, and to ensure a constructive cultural and social role of Islamic institutions in a Muslim society. Hassan's (2005) finding has inevitably become a new empirical basis for explaining the relationship between religion and politics. It reflects that secularism should 
not always be crudely viewed as a categorical resistance against religion. Thus, Muslims have different views regarding Islam's relationship with secularism.

A deeper theoretical approach on secularism was offered by Kuru (2009) based on his comparative research on secular political systems of France, Turkey, and the United States. In his terminology, the three countries are similarly secular as they lack any official religion and have legal systems free from religious control (Kuru, 2007). Yet, they are different from each other on the basis of the acceptance of the public expression of religion. Kuru describes Turkish and French cases as 'assertive secularism' while the American case as 'passive secularism. "Assertive secularism controls religion through the power of the state and does not allow public expression of religion, whereas passive secularism allows public visibility of religion without discriminating" (Kösebalaban, 2013, p.299).

These different views on secularism, among others, as Stepan (2010) argues, are caused by the fact that the secular models of state are multifaceted in their values and practices. The degree to which a state is secular relies on the pattern of state-religion relations, which determine the jurisdictional borders between the two. At one edge of the spectrums are theocratic states, where the states are governed by divinely guided officials. At the other extreme are atheist states, which adopt the ideology that there is no God while embrace 'secular fundamentalism' by imposing strict state-religion separation. Both types are unacceptable in multi-religious societies like Singapore 
(Li-ann, 2007). Amidst these two spectrums, secular democratic nations have embraced types ranging from 'accommodationist' to 'cooperationist' governments.

\section{Secularism in Singapore}

Singapore employs two types of secularism in managing Islam: "muscular secularism (where laws and formal co-optation are used) and calibrated secularism (informal co-optation is used)" (Abdullah, 2012, vii). The co-optation is toward two leading Islamic organizations: "Islamic Religious Council of Singapore" (MUIS) and "Singapore Islamic Scholars and Religious Teachers Association" (Pergas). "MUIS is both formally and informally co-opted, while Pergas is informally (ideologically/psychologically), not constitutionally) coopted" (p.vii).

Besides, Singapore which does not favor one religion over others has elements of both 'accommodationist' and 'cooperatiosnist' in its model of state-religion relations (Li-ann, 2007). For instance, as an accommodationist, Singapore government has officially recognized a number of religious holidays. As a 'cooperationist', Central Provident Fund System has facilitated the collection of Mosque Building Fund contribution. Singapore provides the right of religious communities to adhere to their religious faiths but maintains a separation of religion from the state (Singapore Constitution, 1980). When should religion be separated from the state and vice versa? Parliamentary White Paper (1989) notes: 
...Religious leaders and members of religious groups should refrain from promoting any political party or cause under the cloak of religion. The leaders should not incite their faithful to defy, challenge or actively oppose secular Government policies; much less mobilize their followers or their organizations for subversive purposes (p.6).

Religious groups and organizations are warned not to 'dabble in politics.' In 1977, the Senior Parliamentary Secretary for Labor had warned religious groups not to involve in 'milk powder' politics (Wee, 2005). Any religious activity that is interpreted by the government as overstepping the demarcated bounds is sharply curtailed through what are described as 'stern measures'. For example, it was reported in the Straits Times (October 14, 1976) that the Housing and Development Board would take stern measures to stop Muslim religious meetings in community halls being turned into political forums.

Li-ann (2007) and Tan (2015) have the same views which argue that secularism in Singapore is helpful as a framework to support the co-existence of diverse religions and belief systems, towards which the state is even-handed and neutral, to promote religious peace and harmony, and to appreciate the diversity and complexity that religion presents. Touching on the separation of religion from politics, Li-ann (2007) argues:

The Government is disinterested in the veracity of any religious belief...Singapore's secularism provides a framework for the peaceful coexistence of different religious communities. The constitutional right of religious freedom operates within the structure of public order. Laws like the Maintenance of Religious Harmony Act 
(MHRA) aim to preserve social order. The mixing of religion and politics as when religious group enter into politics or religious sentiments are exploited to mobilize the faithful for subversive purpose typifies such threats (Li-ann, Oktober 30, 2007, p.25).

Referring to Kuru's typology of secularism, Singapore's secularism can be classified as assertive secularism which requires that the state to play an assertive role in excluding religion from politics and the public sphere. Singapore's policies generally ban its public visibility of religion as seen in their prohibition of wearing headscarves by female students in public schools, nurses, front-line immigration, and customs officers.

\section{Religiosity}

Religiosity for some scholars like Coyle (2002), Khraim (2010), and Saleh (2012) is a complex concept and hard to define, partly because the concept recently across various academic disciplines, each differently approaches religiosity based on its own viewpoint and view consults one another (Cardwell, 1980; Demerath, 1969). For instance, a theologian might consider the concept of religiosity from the perspective of faith, whereas religious educators would emphasize on belief and orthodoxy, and psychologists might focus on the dimensions of devotion, piousness, and holiness (Holdcroft, 2006). Many scholars have offered up different definitions, yet thus far, nobody summarizes the whole range of meaning inherent within the term. Schaffer (1996), for instance, describes religiosity as the 
degree of participation in, or faithfulness to the beliefs and practices of a religion. Similarly, Koenig et al. (2012) define religiosity as a set of beliefs and practices relating to the transcendent.

Numerous empirical studies have shown that religiosity is a multidimensional phenomenon (Cornwall et al. 1986; De Jong 1966; El-Menouar 2014; Glock \& Stark, 1965; Pearce et al. 2013; Storm, 2009; ). One of the most influential studies on this issue is Stark and Glock's (1968) study which identify five dimensions of religiosity: ideological, intellectual, ritualistic, experiential, and consequential. The ideological dimension is "constituted by expectations that the religious will hold to certain beliefs, i.e., professed doctrines" (p.20). The intellectual dimension means the hope that a religious person will understand the basic tenets of his belief and holy book. Although 'knowledge of a belief is a necessary condition for its acceptance,' Glock and Stark admitted that "belief does not necessarily flow from knowledge, nor does all religious knowledge accompany belief" (pp. 2021). The ritualistic dimension consists of particular rituals or religious duties as an expression of their religious commitment. While the experiential dimension represents some kinds of individual experience or perceived communication with the Divine reality, the consequential dimension is the effect of religion on the adherents and their daily lives. Thus, religiosity can contain numerous components such as the strength of a person's religious faiths, intensity of religious practices, and salience of religious identity (Stroope \& Baker 2018; 
Vang 2019). People may be highly religious with regard to one dimension and less religious toward others (Bechert 2018; Stark \& Glock, 1968).

From the Islamic perspective, religion is the bond and connection between a worshipper and his God as his creator and the Ultimate Reality. It is a comprehensive way of life (al-din) that shapes its adherents' value systems and worldviews and influences their beliefs, policies, words, and deeds (Shihab, 2005). Moreover, religiosity in Islam is comprehensively explained in a hadith (Shahih Muslim, 1993) which is popular as Hadith Jibril. Religion is a concept with three necessary components encompassing iman, islam, and ihsan. Iman contains the belief and cognitive system in comprehending God, his angels, prophets, scriptures, and resurrection. Then, Islam represents religious obligations indicated by religious practices and rituals such as performance of prayers, almsgiving, fasting, and pilgrimage. Unlike the former components, Ihsan constitutes the inner dimension that covers the spirit and actualization of goodness and virtue or spiritual and moral excellence. It is the highest level that a person could attain, and by reaching it, an Islamic adherent is considered to have completely submitted. These three constituents are not separated but intimately related and required each other to be well-balanced and religious persons (Al-Qaradawi, 2010; Mahudin, 2016; Maududi, 1960). The Islamic perspective on religiosity that contains iman, islam and ihsan fit Glock and Stark's multidimensional concept of religiosity which comprises ideological, intellectual, ritualistic, experiential, and consequential dimensions. 
Many studies have been dedicated by a lot of scholars in developing scales to measure religiosity (Alghorani, 2008; Batson \& Schoenrade, 1991; Glock \& Stark, 1968; Tiliouine et. al, 2009). Although it was developed to measure Christian religiosity, Stark and Glock's multidimensional model of religiosity has been influential in the sociology of religion as it serves as a heuristic tool in order to examine different facets of religiosity (El-Menouar, 2014). El-Menouar (2014) then adapted their model of multidimensional religiosity in developing his new instrument to measure Muslim religiosity, while taking into account certain characteristics of Islamic piety. His further statistical analysis showed that the instruments are internally valid and reliable.

\section{Research Method}

\section{Design}

A survey design was employed to investigate Muslim religiosity in Singapore in which the data were collected from January to March 2020 from 482 convenience respondents through the distribution of questionnaires in some locations in Singapore. To provide adequate depth and richness data, documentation published by the Islamic Religious Council of Singapore were used. Interviews were also conducted between May and June 2021 to 13 respondents ranging from Islamic religious authorities and officials, preachers, imams, Muslim intellectuals, madrasahs teachers, and lecturers. 


\section{Participants}

Total number of participants gathered for this study ( $\mathrm{N}=482)$ consisting of $286(59 \%)$ females and 176 males (41\%). One-third (38.6\%) of the sample are aged 56 years and older; $29 \%$ are aged 41 to 55 years; $22.8 \%$ are aged 25 to 40 years, and $9.5 \%$ are aged 17 to 24 years. These proportions are not consistent with the structure of the total Singaporean population, which is mostly aged 30 to 55 years based on Singapore in Figures 2019. Most of the samples (49.8\%) have their education in secondary education (N/O/A level); $24.5 \%$ have graduated from Diploma/Higher Nitec/Nitec education and 26.6\% have graduated a degree program. This distribution roughly represents the structure of Singaporean Muslim education aged 25 years and over which is predominantly graduated from N/O/A level or secondary education (Singapore Department of Statistic, 2019).

\section{Procedures}

Researcher attended different mosques during January and February 2019 (before the spread of Covid-19), in which 228 Singaporean Muslims agreed to complete the questionnaires. Six of well-known mosques in Singapore were selected for several reasons. The most important reason is that it serves as a focal point for the Singaporean Muslim community of different social classes and diverse ethnic backgrounds. Another reason is its various areas in Singapore which hopefully capture its diversity of sociocultural aspects. A quota sample was also employed in which the questionnaires were distributed to different ages and gender. In other cases, 
online questionnaires using Google form were individually completed by 258 participants in group settings, such as offices, community groups, organizations, classrooms, and even homes inhabited by adults from different social roles and occupations. The sole principle to be included in the sample was being above 17 years old. Thus, the data were collected from the high religious heterogeneity of sample, in terms of age, gender, educational background, and religiosity level. Following the submission of the questionnaire, the respondents were interviewed in order to provide data of adequate richness and depth.

\section{Instruments}

This survey adapted a questionnaire developed by El-Menouar (2014) , adapting Stark and Glock's model of multidimensional religiosity in the sociology of religion, and took into account the particular features of Islamic piety. As addressed in the sections above, the three concepts described in Hadith Jibril are considered the identifying characteristics of Islamic religion and are one way of framing and conceptualizing work in religiosity. Referring to this framework, religiosity is defined as consisting of "three levels of religion: (1) the bodily action or human activity (Islam), (2) the mind or understanding of God (iman), and (3) the spirit or actualization of virtue and goodness (Ihsan)" (Mahudin, 2016,p. 114). These identifying features of Islam fit Stark and Glock's five dimensions of religiosity: ideological, intellectual, ritualistic, experiential and consequential from which El-Menouar (2014) developed his instruments that 
the present study adapts. Information about religiosity level was gathered using 19 items as follows; believing in God (Allah), believing in the Quran as God revelation, believing in the hereafter, knowing Islam in general, the contents of the Quran, and the tradition of the Prophet Muhammad (Hadith), performing ritual prayers, fasting during Ramadhan, paying zakat, performing pilgrimage to Mecca when they meet the necessary means, feeling close to Allah, feeling of being rewarded by Allah, feeling of being punished by Allah, making decisions based on Islamic values, striving to do goodness, avoiding behavior that will be punished in the hereafter, eating halal food, reciting Basmalah before any activity, and reciting personal prayer before and after an activity. This questionnaire also included three items focusing on demographic information such as gender, age, and educational background.

\section{Data Analysis}

Each item of the questionnaire has followed a Likert scale of 5 points: ranging from Strongly Disagree (SD), Disagree (D), Uncertain (UC), Agree (A), to Strongly Agree (SA). The data were presented in the form of a table showing the percentage of the respondent's responses. The collected data were analyzed through several stages: data cleaning, transcribing, coding and categorizing, and interpreting (Miles and Huberman 1994; Patton 2002). 


\section{Findings and Discussion}

\section{Singaporean Muslim Religiosity}

This study investigated how religiosity is experienced and lived among Muslims in Singapore, in which the particular aspects of Islam they are expected to commit, are presented based on the five dimensions of religiosity below.

\section{Ideological Dimension}

This dimension constitutes basic religiosity that represents a minimum commitment on a personal level and, for this reason, is the foundation of Muslim religiosity in general. The respondents were asked whether they believe in the existence of Allah without any doubt, Quran as God revelation, and the hereafter or not.

Table 1: Ideological Dimension

\begin{tabular}{|c|c|c|c|c|c|c|}
\hline No & Item & SD & D & UC & A & SA \\
\hline 1 & Belief in God (Allah) & & & $0.4 \%$ & & $99,6 \%$ \\
\hline 2 & $\begin{array}{l}\text { Belief in the Quran as God } \\
\text { revelation }\end{array}$ & & & $0.4 \%$ & & $99,6 \%$ \\
\hline 3 & Belief in the hereafter & & & & $0.4 \%$ & $99,6 \%$ \\
\hline
\end{tabular}

Table 1 indicates that almost all respondents (99.6\%) strongly agree (SA) that they believe in Allah, in Quran as God's revelation, and in the Day of Judgment. Only $0.4 \%$ of the respondents were uncertain (UC) with the statement about belief in God and Quran as God revelation, and only $0.4 \%$ of them agreed (A) with the statement that they believe in life after death. 
This evidence indicates that Singaporean Muslims are orthodox in their religious belief. In relation to this data, Muslim intellectuals and teachers argued that Islamic religion and ideology has been one of Singaporean Muslim identities thatwere dominant in the past continues to survive in the modern era.

\section{Intellectual Dimension}

To measure the extentofthereligiousunderstanding, the questionnaire asked about respondents' knowledge relating to Islam in general, the contents of the Quran, and Hadith (the life and actions of the Prophet).

Table 2: Intellectual Dimension

\begin{tabular}{|c|c|c|c|c|c|c|}
\hline No & Item & SD & D & UC & A & SA \\
\hline 1 & $\begin{array}{l}\text { Knowledge of Islam in } \\
\text { general }\end{array}$ & & & $4.1 \%$ & $26.1 \%$ & $69.7 \%$ \\
\hline 2 & $\begin{array}{l}\text { Knowledge of the contents of } \\
\text { the Quran }\end{array}$ & $0.4 \%$ & $1.2 \%$ & $19.9 \%$ & $35.7 \%$ & $42.7 \%$ \\
\hline 3 & $\begin{array}{l}\text { Knowledge of the contents of } \\
\text { Hadith }\end{array}$ & $0.4 \%$ & $2.5 \%$ & $21.6 \%$ & $37.8 \%$ & $37.8 \%$ \\
\hline
\end{tabular}

As reported in Table 2, participants' responses show that most of the respondents (69\%) are very sure that they know Islam in general, while almost half of them (42.7\%) strongly agree that they know the contents of the Quran. Strikingly different from the previous items, only about one-third (37\%) of respondents strongly agree that they know the contents of Hadith. However, about one-third of the respondents agree that they know Islam in general, 
the contents of the Quran and Hadith. A somewhat small percent ranging from $4.1 \%$ to $37.8 \%$ are not sure about their knowledge of Islam in general, the contents of the Quran and Hadith. These findings show that Singaporean Muslims' knowledge of Islam, in general, is different from their knowledge of the contents of Quran and Hadith, where the latter is slightly unknown compared to Quranic exegesis and Islam in general. This dimension is relatively low compared to other dimensions. It might relate to the fact that government excludes religious knowledge from formal education (except madrasahs with limited quota), while informal education focuses mainly on compulsory acts that must be observed by each personal Muslim (fardhu 'ain).

\section{Ritualistic Dimension}

Four Islamic rituals usually observed by Muslims were employed to measure the ritualistic dimension of religiosity. Most respondents $(80.1 \%)$ observed praying five times every day. They are significantly more observant of fasting during the month of Ramadhan (90.5\% of respondents) and paying their zakat obligations ( $91.3 \%$ of respondents).

Table 3: Ritualistic Dimension

\begin{tabular}{lllllll}
\hline No & Item & SD & D & UC & A & SA \\
\hline $\mathbf{1}$ & $\begin{array}{l}\text { Frequency of performing the } \\
\text { ritual prayer }\end{array}$ & 0.4 & 1.7 & 2.6 & $15.2 \%$ & $80.1 \%$ \\
$\mathbf{2}$ & $\begin{array}{l}\text { Frequency of fasting during } \\
\text { Ramadhan }\end{array}$ & $0.4 \%$ & & $1.2 \%$ & $7.9 \%$ & $90.5 \%$ \\
$\mathbf{3}$ & Almsgiving (zakat) & & $0.4 \%$ & $2.1 \%$ & $6.2 \%$ & $91.3 \%$ \\
$\mathbf{4}$ & Pilgrimage to Mecca & $21.2 \%$ & $10.8 \%$ & $10.4 \%$ & $4.6 \%$ & $53.1 \%$ \\
\hline
\end{tabular}


This finding fits the MUIS (Majlis Ulama Islam Singapura) Annual Report (2018) on zakat in which there is an increasing zakat collection from 2014 to 2018.

Figure 1: Zakat Collection

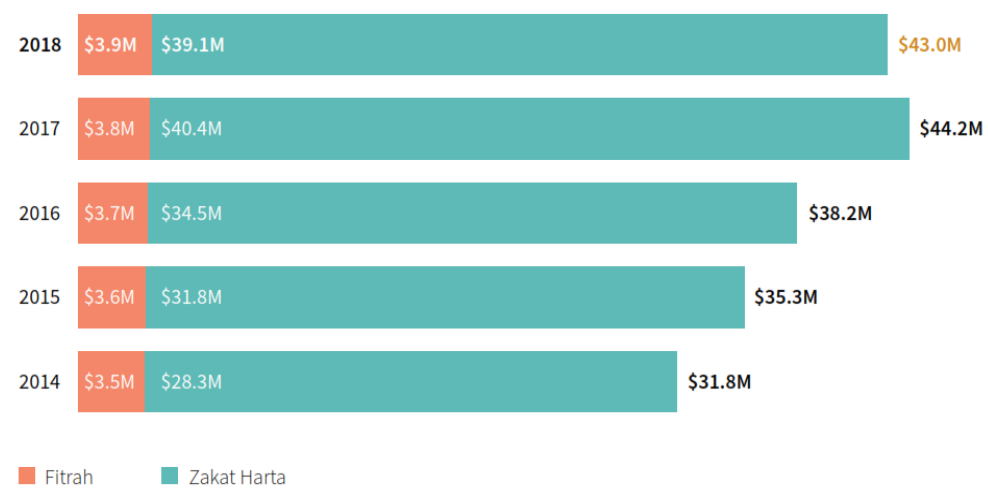

About half (53.1\%) of the respondents performed the pilgrimage to Mecca. The rest did not perform it yet because of the quota limit. However, based on MUIS Annual Report (from 2015 to 2018), there was an increasing number of pilgrims based on quota available, as the following table show:

Table 4: Total Number of Pilgrims

\begin{tabular}{ccc}
\hline No & Total Number of Pilgrims & Year \\
\hline $\mathbf{1}$ & 680 & 2015 \\
$\mathbf{2}$ & 680 & 2016 \\
$\mathbf{3}$ & 800 & 2017 \\
$\mathbf{4}$ & 850 & 2018 \\
$\mathbf{5}$ & 900 & 2019 \\
\hline
\end{tabular}

\section{Experiential Dimension}

This dimension represents some kind of individual experience or communication with the ultimate divine 
reality. As Table 5 shows, $89 \%$ of the respondents strongly agree that they feel close to Allah and being rewarded by Allah, and $78 \%$ strongly agree that they had the sense of getting punishment from Allah. It means that for the majority of Singaporean Muslims, feeling the presence of Allah, feeling rewarded and punished by Allah are an essential part of their experience of the ultimate divine truth. The interviewed religious authorities and officials affirmed that Islamic religion and ideology have been deeply embedded in Singaporean Muslims and have strongly influenced their way of thinking and feeling.

Table 5: Experiential Dimension

\begin{tabular}{|c|c|c|c|c|c|c|}
\hline No & Item & SD & D & UC & A & SA \\
\hline 1 & Feeling of Allah is close & & & $1.7 \%$ & $8.7 \%$ & $89.6 \%$ \\
\hline 2 & Feeling of being rewarded by Allah & & & $1.7 \%$ & $8.7 \%$ & $89.6 \%$ \\
\hline 3 & Feeling of being punished by Allah & & & $4.6 \%$ & $17 \%$ & $78 \%$ \\
\hline
\end{tabular}

\section{Consequential Dimension}

This dimension indicates the secular effect of religious faith, experience, and practice. As the following table presents, almost two-thirds of the respondents strongly agree that they frequently make decisions based on Islamic teaching, always strive to do goodness and always try to avoid behavior that will be punished in the hereafter. They are significantly more observant of eating only halal food. 
Table 6: Consequential Dimension

\begin{tabular}{|c|c|c|c|c|c|c|}
\hline No & Item & SD & D & UC & A & SA \\
\hline 1 & $\begin{array}{l}\text { Frequency of making decisions } \\
\text { based on Islamic teaching }\end{array}$ & & & $8.3 \%$ & $24.9 \%$ & $66.8 \%$ \\
\hline 2 & $\begin{array}{l}\text { Frequency of striving to do } \\
\text { goodness }\end{array}$ & & & $1.9 \%$ & $22.1 \%$ & $76.1 \%$ \\
\hline 3 & $\begin{array}{l}\text { Frequency of avoiding behavior } \\
\text { that will be punished in the } \\
\text { hereafter }\end{array}$ & & $0.5 \%$ & $10.3 \%$ & $22.1 \%$ & $67.1 \%$ \\
\hline 4 & Only eating halal food & & & $3.3 \%$ & $7.9 \%$ & $88.8 \%$ \\
\hline
\end{tabular}

In relation to this finding, a study participant who is a lecturer of Islamic studies argued that 'Islam has strongly influenced Singaporean Muslim's life, many Islamic values had been integrated and assimilated into the way they live their life, as Islam does not only guide its adherent to the right conduct of the religious ritual but also regulates the daily life of the adherents.' Their obedience is to be conceived as religious worship, which is a critical point.

\section{Devotional Dimension}

This dimension represents acts of worship outside social and formalized rituals in which a pious Muslim spontaneously performs them in privacy.

Table 7: Devotional Dimension

\begin{tabular}{|c|c|c|c|c|c|c|}
\hline No & Item & SD & D & UC & A & SA \\
\hline 1 & $\begin{array}{l}\text { Frequency of beginning an activity } \\
\text { by reciting Basmalah }\end{array}$ & & $0.4 \%$ & $6.2 \%$ & $19.5 \%$ & $73.9 \%$ \\
\hline 2 & $\begin{array}{l}\text { Frequency of personal prayer to } \\
\text { Allah before and after an action }\end{array}$ & & & $7.5 \%$ & $32 \%$ & $60.6 \%$ \\
\hline
\end{tabular}


As the above table shows, almost two-thirds (73\%) of the respondents strongly agree that they frequently begin their activities by reciting basmalah. 60.6\% of them strongly agree and $32 \%$ of them agree that they frequently place their actions under God's protection and hope that they are successful. Only $7.5 \%$ of them were not certain to do so. An interviewed ustadz argued that reciting basmalah before doing any activity means seeking help and blessing to whom our hearts turn in veneration, obedience and love. Meanwhile, reciting hamdalah means praise and thank Allah for His favors and bounties.

Looking at the index of each dimension above, this empirical evidence shows that the overwhelming majority of Singaporean Muslims are quite religious. Their high religiosity can be seen from their relatively high involvement in their religion, such as religious rituals and devotion. The finding also indicates a high degree of referring to the transcendence and integrating religion in their daily lives as proved through their Islamic knowledge and belief, experience and consequence. Moreover, their religiosity is strongly grounded in Islamic knowledge and belief, religious ritual, experience, consequence, and devotion. All dimensions of their religiosity appear to be correlated, meaning that Muslims, who have a high degree in their manifestation of Islam, have robust Islamic knowledge and faith. Further analysis of the evidence indicated that females scored insignificantly higher than males in their religiosity. It also shows that religiosity increases with age, in which the oldest Muslims are the most pious and religious. 


\section{Becoming Religious Muslims in the Secular State}

It seems paradoxical when the Muslim minority is quite religious while they are living in a secular state. However, it was possible in the Singaporean context, owing to the nature of Singapore's secularism that does not require the loss of faith and does not explicitly prevent its people from observing their religious obligations (Kadir, 2004). Former Minister George Yeo declared that Singapore's government is secular, but it is certainly not atheistic. It is considerably neutral (Li-ann, 2007). This vision shows that the government adopts pragmatic and strategic secularism in order to accommodate $80 \%$ of Singaporeans who are religious followers. The state's pragmatic and strategic secularism is shown by the authority's practical policies in its intervention toward the administration of religions including Islam (Sebastian, 2010). While religion should maintain its private domain, the state nevertheless manages it from the public domain in its attempts to preserve religious and social harmony. This is most observable in relation to Islam. Islam is managed through the establishment of the Administration of Muslim Law Act (AMLA) and the founding of the Islamic Religious Council of Singapore or MUIS. AMLA addresses some issues like MUIS, mosque and religious schools, the sharia court, marriage and divorce, Muslim financial provisions, property, halal and haj matters, religious offenses, conversions, and miscellaneous (Nasir, 2010). Established in 1968 as part of the AMLA:

MUIS become a state-sponsored religious 
bureaucracy with statutory board status that has centralized Muslim affairs. It administers the zakat collection, wakaf land, haj pilgrimages and manages nearly 100 mosques. It also administers the Mosque Building Fund (MBF) which collects financial contributions from working Singaporeans for the building and maintenance of mosques in housing estates. MUIS has the power to approve nominees to mosque management committees and provides the text of Friday mosque sermons. From 1975, all pilgrims had to register with MUIS and could only perform the haj through MUIS approved vendors (Rahim, 2012, p.4-5).

Despite thestateostensiblyreinforcingtheseparation of religion and politics, it continues to govern Islam and manage religion. The state also prohibits religious leaders and organizations from engaging in political measures but stimulates them to liaise with the government in implementing the state's policies. Rahim (2012) argues that the separation of religion and politics only applies to the citizenry and not the PAP government. This hasled some researchers to label Singapore's secularism as 'pragmatic secularism' or 'strategic secularism' (Osman, 2018). As Musa (2017) noted that the Singapore's relationship with religion had been one of pragmatism, based on the fact of the state's multi-religious and multi-racial society. He argued that to survive against the odds, the state needs a strong centralized government that subordinates all institutions temporally and spiritually. The state gives space to religion generally but asserts its authority when it is needed to preserve social peace and maintain long-term economic prosperity. 
Thus, secularism in the Singapore context where the state maintains separation of religion from the state, the most prominent Islamic organizations like MUIS and Pergas hold high esteem from their Muslim community. These religious organizations play important roles in governing Islam although they are under state co-optation and control (Abdullah, 2012). Religious institutions are engaged in playing an essential role in the state's most pressing development issues. They are involved in offering aid on the front lines of crises and in influencing the Muslim community in fundamental ways such as empowering human resources through Islamic education, empowering the poor through zakat, and forging the Singaporean Muslim identity that is compatible with the principle and practice of 'hard multiculturalism' in Singapore (MUIS, 2018, 2017, 2016, 2015). Referring to Feener (2018) concerning 'religion and development,' this fact reflects the contemporary entanglements of religion and development, in which religion and development run by the state interact and mutually benefit each other. Touching on the role of religion, Mr Lee said that the government recognizes its importance in meeting Singaporeans' spiritual, moral, and ethical needs, particularly in a period of rapid economic and social transformation (Business Times, August 17, 1987). This affirms Feener's argument that religion has been profoundly reconfigured in the age of development.

Under such governance and regulation toward Islam and Muslims, Singaporean Muslims have observed their religious obligations. They have managed to build 
mosques, improve their religious knowledge, strengthen their religious resilience, heighten madrasahs' credibility and quality as educational institutions, collect and disburse zakat for social development and assistance for poor and needy, perform the pilgrims, certify halal food and products, and other religiousactions especially under MUIS administration, . These results align with MUIS prioritized strategy which is setting the Islamic agenda, shaping religious life, and forging the Singaporean Muslim identity. As MUIS continues to voice and instill in the Muslim community, Singapore's Muslim identity includes believing that good Muslims are also good citizens, adapting well as contributing members of the secular state and multi-religious society, keeping strongly to Islamic teachings while adjusting itself to changing circumstances, appreciating Islamic civilization and history and having a proper understanding of current issues. MUIS has always worked closely with the community and has run various programs to establish such an identity as MUIS has annually reported (MUIS, 2018, 2017, 2016, 2015).

Another explanation of how Singaporean Muslims can experience their religiosity in a secular state like Singapore lies in their ability to negotiate a balance between their religious obligations as Muslims and their responsibilities and duties as Singaporeans. For instance, when there is no religious knowledge in public schools, Muslim students can enroll in one of six full-time Madrasahs (Al-Irsyad, Aljuneid, Al-Ma'arif, Al-Arabiyah, Wak Tanjong, and Alsagoff) in order to gain Islamic 
education (Mokhtar, 2010). For those who are not lucky to gain seats in such formal Islamic institutions due to quota limit by the state, they can seek to learn religious knowledge in part-time madrasahs or mosques. Adult Muslims can also access Islamic learning through a program named ADIL (Adult Islamic Learning) developed by the Office of the Mufti to be intellectually enriched, spiritually refreshed, and meaningfully engaged in daily lives. Meanwhile, Singaporean Muslims also observe state acts like the Internal Security Act (ISA) and the Maintenance of Religious Harmony Act (MRHA) that govern religions including Islam and regulate believers including Muslims. Even though Islamic organizations like MUIS and Pergas are allowed to become agents of change and social development and to provide welfare services, they are not dabbled in politics.

Indeed, for the Muslims of Singapore, there have been some complexities in meeting their religious expectations to be completely accommodated, as it is stated in the beginning. However, there are numerous prospects where Islam has continued to flourish within this multi-religious and secular state. For instance, legal pluralism as practiced in the state enables them to adhere to their religious tradition by recognizing some facet of the Islamic law to be acknowledged as part of Singapore's law. Through AMLA, the secular state acknowledges the necessity for Muslims to comply with their provision of law on issues regarding family law and many aspects of Islamic life. Besides, it proves that some parts of the Islamic law and jurisprudence have been integrated into 
the official state's law that regulates Muslims. The success of legislative harmonization between civil and Islamic law delivers an important note of respect for sharia, which is inclusive and affirming, and accordingly permits minority aspirations and values to be acknowledged.

\section{E. Conclusion}

This study finds that the majority of Singaporean Muslims are generally quite religious. It is indicated by the high consistency and similarity in their multidimensional elements of religiosity, including ideological, intellectual, ritualistic, experiential, consequential, and devotional dimensions. It means that religion is being the core of their identity and major component of their life, despite living within a secular state.

Although many Singaporean Muslims face difficulties in accommodating the idea of secularism into their worldview as Muslims, their experiences indicate that Muslim commitment and piety can peacefully coexist within the state secularism. It is owing to the unique nature of Singapore's secularism which is not hostile to Islam and does not disrupt the Islamic characters. The same features happen in Indonesia, India, and Senegal, where secularism and Islam are not mutually exclusive (Stepan, 2010). This finding is also in line with Hassan's study (2005) on Muslim religiosity in Muslim countries such as Indonesia, Malaysia, and Turkey that is found to be high. Thus, secularism should not always be crudely viewed as a categorical resistance against religion since there are multiple secularisms and it has not have the same shapes in relation to different cultural and political milieus and different religions. 
The high degree of Singaporean Muslim religiosity is also owing to their ability in negotiating a prudent balance between their responsibilities and duties as Singaporeans and their religious obligations as Muslims. Considering the social and political background as a secular and multi-religious state, the empirical evidence presented in this study proves that strong religiosity among ummah is very much a reality in Singapore. Therefore, Islam is not a stagnant and unchanging phenomenon as it is generally perceived to be.

\section{REFERENCES}

Abdullah, W. J. (2012). Religious Representation in Secular Singapore: A Study of MUIS and Pergas [Thesis, National University of Singapore]. University Repository.

Abdullah, W. J. (2013). Religious representation in secular Singapore: A study of MUIS and Pergas, Asian Survey, 53(6). http: / / scholarbank.nus.edu.sg / handle/10635/36549

Al-Attas, S. M. N. (1993). Islam and secularism. Kuala Lumpur: ISTAC.

Alghorani, M. A. (2008). Knowledge-practice measure of Islamic religiosity (KPMIR): A case of high school Muslim students in the United States. Journal of Muslim Mental Health, 3, 25-36. https://doi. org/10.1080/15564900802035169

Al-Nasaiburī, Abī al-Ḥusain Muslim Ibn al-Hajjāj. (1414 H/1993M). Sahịị̣ Muslim, Beirūt: Dār al-Fikr, hadith No. 8, p. 36.

Al-Qaradawi, Y. (2010). Islam an introduction. Kuala Lumpur: Islamic Book Trust. 
Al-Qaradawi, Y. (1997). Al-Islam wa al-'ilmaniyyah wajhan li wajhin. Kairo: Maktabah Wahbah.

Amer, M. M. (2021). Measures of Muslim religiousness constructs and a multidimensional scale. In M. M. Ai. (Ed.), Assessing spirituality in a diverse world, Cham, Switzerland: Springer Nature Switzerland AG.

An-Na'im, A. A. (2008). Islam and the secular state: Negotiating the future of shari' $a$. Cambridge, Massachusetts: Harvard University Press.

Kösebalaban, Hasan. (2013). Secularism and state policies toward religion: the United States, France, and Turkey. Ahmet T. Kuru, Cont Islam , 7, 229-231. Doi: 10.1007/s11562-011-0155-X

Batson, C. D., \& Schoenrade, P. A. (1991). Measuring religion as quest: Validity concerns. Journal for the Scientific Study of Religion, 30 (4), 416-429. https://doi. org/10.2307/1387277

Bechert, I. (2018). Comparing religiosity cross-nationally. $Z$ Religion Ges Polit, 2, 135-157. doi:10.1007/s41682018-0016-z

Cardwell, J. D. (1980). The social context of religiosity. Lanham, MD: University Press of America.

Clayton, T. (2001). A review of the Singapore dilemma: The political and educational marginality of the Malay community. The Journal of Asian Studies, 60(4), 12421244.

Cornwall, et al. (1986). The dimensions of religiosity: A conceptual model and an empirical test. Review of Religious Research, 27(3), 226-244. https://doi. org/10.2307/3511418

Coyle, J. (2002). Spirituality and health: Toward a framework for exploring the relationship between spirituality and 
health. Journal of Advanced Nursing, 37(6), 589-597. https://doi.org/10.1046/j.1365-2648.2002.02133.x

Demerath, N. J., \& Hammond, P. E. (1969). Religion in social context: Tradition and transition. New York: Random House.

Department of Statistics. (2015). Executive Summary, Department of Statistic Singapore. https://www. singstat.gov.sg/-/media/files/publications/ghs/ ghs2015/executive-summary.pdf

Department of Statistics. (2019). Singapore in figures 2019 (ISSN: 2591-7889). Department of Statistic Singapore. www.singtat.gov.sg

El-Menouar, Y. (2014). The five dimensions of Muslim religiosity: Results of an empirical study. Methods, Data, Analyses, 8(1), 53-78. https://doi.org/10.12758/ MDA.2014.003

Esposito, J. L. (1998). Rethinking Islam and secularism. (Guiding Paper Series of the ARDA). Retrieved from http://www.thearda.com/rrh/papers/guidingpapers/ Esposito.pdf

Feener, R M., \& Fountain, P. (2018). Religion in the age of development. Religions, 9(12), 382. doi: 10.3390/ rel9120382.

Gallup. (2009). The Gallup coexist index 2009: A global study of interfaith relations - with an in-depth analysis of Muslim integration in France, Germany and the United Kingdom. Gallup, Inc.

Glock, C. Y. \& Stark, R. (1965). Religion and society in tension. San Francisco: Rand McNally.

Hassan, R. (1999). Faithlines: Religion, society and the state in Indonesia and Pakistan. Islamic Studies, 38(1): 45-62. https://www.jstor.org/stable/20837025 
Hassan, R. (2002). Faithlines: Muslim conceptions of Islam and society. Oxford: Oxford University Press.

Hassan, R. (2005, June). On being religious: Patterns of religious commitment in Muslim societies [Conference Presentation]. Institute of Defense and Strategic Studies, Singapore.

Hashemi, N. (2009). Secularism. In J. L. Esposito (Ed.), The Oxford Encyclopedia of the Islamic World. Oxford: Oxford University Press.

Holdcroft, B. B. (2006). What is Religiosity. Journal of Catholic Education. 10(1), 89-103. doi: 10.15365/ joce. 1001082013

Kadir, S. (2004). Islam, state and society in Singapore. InterAsia Cultural Studies, 5(3), 357-371. https://doi. org/10.1080/1464937042000288660

Khraim, H. (2010). Measuring religiosity in consumer research from Islamic perspective. International Journal of Marketing Studies, 2(2), 166-179. DOI:10.1108/10264116201000003

Koenig, H. G., King, D. E., \& Carson, V. B. (2012). Handbook of religion and health (2nd ed.). Oxford: Oxford University Press.

Kuru, A. T. (2007). Passive and assertive secularism: Historical conditions, ideological struggles, and state policies toward religion, World Politics, 59(4), pp. 586-594. https://doi. org/10.1353/wp.2008.0005

Kuru,A. T. (2009). Secularism and State Policiestoward Religion: The United States, France, and Turkey (Cambridge: Cambridge University Press.

Lapidus, I. M. (1975). The separation of state and religion in the development of early Islamic society. International Journal of Middle East Studies, 6(4), 363-385. https:// doi.org/10.1017/S0020743800025344 
Lauziere, H. (2013). Secularism. In Bowering, G., \& Crone, P. (Eds.) The Princeton encyclopedia of Islamic political thought. Princeton University Press.

Li-ann, T. (October 30, 2007). Secularism, the Singapore way. The Straits Times.

Mahudin, N. M., Noor, et al. (2016). Religiosity among Muslims: A scale development and validation study. Makara HubsAsia, 20(2), 109-120. Mahudin, N. M., Noor, et al. (2016). Religiosity among Muslims: A scale development and validation study. Makara Hubs-Asia

Maududi, S. A. A. (1960). Toward understanding Islam. Lahore: U.K.I.M Dawah Centre.

Miles, M. B, \& Huberman, A. M. (1994). Qualitative data analysis: An expanded sourcebook. Thousand Oaks: Sage.

Mokhtar, I. A. (2010), Madrasahs in Singapore: Bridging between their roles, relevance and resources. Journal of Muslim Minority Affairs, 30(1), 111-125. https://doi. org/10.1080/13602001003650663

MUIS Academy. (2011). Survey Report on Religious Outlook of the Singapore Muslim Community. Islamic Religious Council of Singapore.

MUIS. (2018). Striving with Confidence Serving with Compassion, Annual Report 2018. Islamic Religious Council of Singapore.

MUIS. (2017). Shaping Religious Life, Annual Report 2017, Islamic Religious Council of Singapore.

MUIS. (2016). Strengthening Our Institutions Harnessing Our Assets, Annual Report 2016. Islamic Religious Council of Singapore.

MUIS. (2015). Strengthening Institutions Empowering Community, Annual Report 2015. Islamic Religious Council of Singapore. 
Musa, M. A. (2017, 21 August). Engaging religion with pragmatism [Conference presentation]. The RSIS Working Paper Series, S. Rajaratnam School of International Studies Singapore, Singapore. https:// www.rsis.edu.sg/rsis-publication

Musa, M. A. (2019). Islam and secularism in Singapore: Between embracement and belief. Interreligious Relations. A. Saeed \& P. Hedges (Eds). (Occasional Paper of The studies in Inter-Religious Relations in Plural Societies Programme). Retrieved from

https://www.rsis.edu.sg/wp-content/ uploads/2019/04/IRR-Issue-3-April-2019.pdf

Mutalib, H. (2012). Singapore Malays, being ethnic minority and Muslim in a global city-state. New York: Routledge.

Nasir, K. M., Alexius A. P., \& Bryan S. T. (2010). Muslims in Singapore: Piety, politics and policies. London and New York: Routledge.

Osman, M. N. M. (2018). The secular and the religious in the management of Islam in Singapore. Journal of Muslim Minority Affairs, 38(2), 246-262. https://doi.org/10.10 $80 / 13602004.2018 .1466486$

Pearce, L. D. et al. (2013). A person-centered examination of adolescent religiosity using latent class analysis. Journal for the Scientific Study of Religion, 52(1), 57-79. doi: 10.1111/jssr.12001

Patton, M. Q (2002). Qualitative evaluation and research methods. London: Sage Publications.

Rahim, L. Z. (2012). Governing Muslims in Singapore's secular state. Australian Journal of International Affairs, 66(2), 169-185. https://doi.org/10.1080/10357718.2011.64 $\underline{6483}$ 
Rahim, L. Z. (2001). The Singapore dilemma: The political and educational marginality of the Malay community. Kuala Lumpur: Oxford University Press.

Raiya, H. A., Pargament, K.I., Mahoney, A., \& Stein, C. (2008). A psychological measure of Islamic religiousness: Development and evidence for reliability and validity. The International Journal for the Psychology of Religion, 18, 291-315. https://doi. org/10.1080/10508610802229270

Sahin, A., \& Francis, L. J. (2002). Assessing attitude toward Islam among Muslim adolescents: The psychometric properties of the Sahin-Francis scale. Muslim Education Quarterly, 19, 35-47. http://dx.doi. org/10.1080/15564900802035201

Salleh, M. S. (2012). Religiosity in development: A theoretical construct of an Islamic-based development. International Journal of Humanities and Social Science, 2(14), 266-274.

Sebastian, R. (2010). Religious managerialism in Singapore: Analysis of statement management of NRMs. In M. Haneda (Ed), Secularization, Religion and the State, Tokyo: University of Tokyo Centre.

Shihab, M. Q. (2005). Tafsir al-mishbah pesan kesan dan keserasian al-Quran (Vol 2). Jakarta: Lentera Hati.

Saeed, A. (2017). Secularism, state neutrality, and Islam. In P. Zuckerman \& J. R. Shook (Eds.), Oxford: Oxford University Press.

Schaffer, H. R. (1996). Social development. Oxford: Blackwell.

Singapore Constitution. (1980) Reprint of the Constitution of the Republic of Singapore, incorporating all amendments ... up to 31 March 1980. Singapore: Attorney-General. 
Stark, R. \& Glock, C.Y. (1968). American piety: The nature of religious commitment. Berkeley: University of California Press.

Steiner, K. (2011). Religion and politics in Singapore: Matters of national identity and security, a case study of the Muslim minority in a secular state. Osaka University Law Review, 58, 107-134. https://research.monash.edu/ en/publications/religion-and-politics-in-singaporematters-of-national-identity-a

Stepan, A. (2010, September 2-5). The multiple secularism of modern democratic and non-democratic regimes [Conference presentation]. American Political Science Meeting, Washington D.C.

Storm, I. (2009). Halfway to heaven: Four types of fuzzy fidelity in Europe. Journal for the Scientific Study of Religion, 48(4), 702-771. https://doi.org/10.1111/ j.1468-5906.2009.01474.x

Stroope, S., \& Baker, J. O. (2018). Whose moral community: Religiosity, secularity, and self-rated health across communal religious contexts. Journal of Health and Social Behavior, 59(2), 185-199. https://doi. org/10.1177/0022146518755698

Tan, C. (2007). Narrowing the gap: The educational achievements of the Malay community in Singapore. Intercultural Education, 18(1), 71-82. DOI:10.1080/14675980601143710

Tan, E. K.B. (2015). Keeping the faith: A study of freedom of thought, conscience, and religion in ASEAN, Human Rights Resources Centre, University of Indonesia.

Tan, J. (1997). Improving Malay educational achievement in Singapore: Problems and policies. Asia Pacific Journal of Education, 17(1), 41-57. https://doi. org/10.1080/02188799708547742 
Tan, K. Y. L. (2016). Law, religion, and the state in Singapore. The Review of Faith \& International Affairs, 14(4), 65-77. doi:10.1080/15570274.2016.1248537

Tey, T. H. (2008). Excluding religion from politics and enforcing religious harmony-Singapore-style. Singapore Journal of Legal Studies, 118-142. http://www.jstor.org/ stable/24869353

Tremewan, C. (1994). The Political Economy of Social Control in Singapore. UK: Palgrave Macmillan.

Vang, Z.M., Hou, F. \& Elder, K. (2019). Perceived religious discrimination, religiosity, and life satisfaction. Journal of Happiness Studies, 20, 1913-1932. https://doi. org/10.1007/s10902-018-0032-x

Wee, V. (2-10 May 1989). Secular state, multi-religious society: The patterning of religion in Singapore [Conference presentation on Religion and Authority in East and Southeast Asia]. Hua Hin, Thailand.

Wilde, A., \& Joseph, S. (1997). Religiosity and personality in a Moslem context. Personality and Individual Differences, 23(5), 899-900. https://doi.org/10.1016/S01918869(97)00098-6

White Paper. (1989). Maintenance of religious harmony: Presented to Parliament by command of the President of the Republic of Singapore, ordered by Parliament to lie upon the table. Singapore: Government of Singapore.

Zoohri, W. H. (1990). The Singapore Malays: The dilemma of development. Singapore: Singapore Malay Teachers Union. 